\title{
COMPREHENSION, ATTITUDES, OBSTACLES, AND ENDEAVORS OF UNIVERSITY STUDENTS DEALING WITH SCIENTIFIC PAPER PUBLICATION AS A PASSING REQUIREMENT
}

\author{
Achmad Supriyanto \\ Department of Educational Management \\ State University of Malang, Indonesia \\ a.supriyanto.fip@um.ac.id
}

\author{
Raden Bambang Sumarsono \\ Department of Educational Management \\ State University of Malang, Indonesia \\ rbamsum@gmail.com
}

\begin{abstract}
The present study is aimed to investigate comprehension, attitudes, obstacles, and endeavors of university students when dealing with scientific paper publication as a passing requirement. This is a descriptive study. The population and sample are students who are currently struggling with scientific paper publication. The data gathered using a questionnaire are analyzed with analytic descriptive technique. Then, the study found that: (1) comprehension of the university students dealing with the scientific paper publication is in the moderate category; (2) the attitudes are also categorized as moderate; (3) the obstacles faced by the students when dealing with the scientific paper publication is moderate as well; and (4) the endeavors they make to cope with the obstacles that occur when dealing with the scientific paper publication as a passing requirement also indicates moderate.
\end{abstract}

Keywords: comprehension, attitudes, obstacles, endeavors of university students, scientific paper publication

\section{INTRODUCTION}

One of the indicators for university students is their capability to complete the publication of scientific paper as a passing requirement. It is initiated as reflection of the concern to the fact of lower scientific paper publication in Indonesia compared to the neighboring country, Malaysia. The Indonesian government has made their response by issuing a Form Letter of Directorate General of Higher Education (Dikti), Ministry of Education and Culture of Indonesian Republic No. 152/E/T/2012 on Scientific Paper Publication. The letter has reaffirmed that following August 2012, the policy of scientific paper publication in scientific journals for passing Bachelor's degree, national scientific journal, acceditated by Dikti is preferred, for passing Master's degree, and international scientific journal for passing Doctoral's degree will be enacted.

Many responses emerge following the enactment of the aforementioned policy, as mentioned by Zain (2013) that supports for the policy should be upheld because it aims for good, especially for pushing scientific paper publication by Indonesian scholars. Djamaan (2016) also utters his respons that: "We should appreciate the Ministry of Education and Culture, through the Directorate General of Higher Education (Dikti), for their incredible courage to issue the Form Letter dated on 27 January 2012 (No. $152 / \mathrm{E} / \mathrm{T} / 2012$ ) on the policy of publishing scientific paper of students of Bachelor, Master, and Doctorate."

It is natural to see pros and cons in the responses from concerned parties. They are with their own rationales. For the pro parties, they believe that scientific paper publication will reflect the quality of the graduates and the prestige of the university, and will improve the university's quality to the wider extent (international). On the other hand, the contra side would argue that it hampers the students' study process by lengthening it, students are also not ready, and that there is only limited number of journals. All these rationales often emerge in the debate of the policy of scientific paper publication as a passing requirement.

Additionally, the policy of scientific paper publication which has been implemented in higher education should have been understood by university students thus taken as a stimulus. In responding to the stimulus, it should be manifested by the students in the form of attitudes towards the policy. It is confirmed with the theory proposed by Ivan Petrovich Pavlov (1849-1936) which is also known as the theory of associative conditioning of stimulus-response. As a relatively new policy faced by university students, it is common to see obtacles following its implementation. Based on an observation conducte by the researcher, especially towards undergraduate students, several obstacles are found in aspects, like: writing system, content, and writing organization that is in accordance with standardized norms of writing scientific paper. One student faces different obstacles from the other, therefore it is necessary to find out the tendency of such obstacles in prospective research.

Such obstacles are not to be ignored for a long time, but immediate attempts should be made by the students to cope with them. The students' independence is demanded in this matter. They can read and review related literature, consult the experts in writing and publishing scientific paper, and discuss with peers who are struggling with the same journey of publishing scientific paper. Furthermore, these obstacles should be revealed thus further investigation can be done.

With such bases, it is necessary to give more concerns especially for Bachelor's degree in fulfilling the passing requirement of publishing scientific paper. First, university students should understand things related with scientific paper and its publication as the requirement for receiving the Bachelor's degree from the university. Second, every student should hold an attitude or response towards the publication requirement. Positive attitudes as a response to the requirement may be manifested in their serious 
endeavors in organizing their paper. The student's comprehension and positive attitude towards the policy can add to their seriousness in completing the requirement of writing scientific paper and publishing it. Still, they will face upcoming obstacles, thus they are demanded to cope with them and complete the requirement eventually.

Despite the pros and cons, the policy of scientific paper publication must be implemented by higher education institutions and completed by the university students. By conducting a study related to this issue, comprehension, attitudes, obstacles, and endeavors of the university students towards the passing requirement of scientific paper publication, which indirectly can reflect the quality of graduates and educational process in the corresponding universities.

The present study is the continuance of the previous study regarding the Scientific Paper Publication. A previous study (Supriyanto, et al., 2015) found that:(1) in term of the higher education institution's attempt to improve the publication quality of student's scientific paper is classified as good (prepared), (2) supporting factors which can enhance the quality of students' paper publication are found in the elements of organizing management of scientific paper publication, especially in giving coaching and training to students for writing scientific paper, (3) obstacles in enhancing the publication quality of student's scientific paper are identified, among others are the support for the implementation of such policy is not yet optimal; and (4) several strategies that are used by univerisities to improve the student's publication quality are revealed, such as:writing scientific paper as one of passing requirements for all students of bachelor, master, and doctorate is considered as a good movement, including the need to publish paper in international scale.

The aforementioned study focuses more on the institution's readiness in implementing the policy of scientific paper publication issued by Dikti. In other words, this study is institution-based. The findings therefore are not comprehensive enough to be implemented to other perspectives, such as the university students as the main subject of the policy of publishing scientific paper as a passing requirement. The definition of scientific paper publication can be taken from the Rector's Regulation of Universitas Negeri Malang No. 17 of 2015 on Education Manual of Universitas Negeri Malang in the Academic Year of 2015/2016. It is noted in this regulation that in Chapter VIII of Scientific Paper Publication, Section 58 mentions that scientific paper publication include articles, creative work, academic work publication, nationally reputed scientific journal, internationally reputed scientific journal, national proceeding, international proceeding, and creative work publication.

Scientific paper publication is variously defined. It encompasses academic work, academic work publication, nationally reputed scientific journal, internationally reputed scientific journal, national proceeding, international proceeding, and creative work publication. All must be understood and taken as an alternative to fulfill scientific paper requirement as a passing requirement in university level. Such status of scientific paper publication has clarified that university students are required to complete the publication in order to be graduated. Every degree is with its own criteria and conditions. Academic work publication should meet all predetermined conditions. Every student is expected to attend to all conditions so that their published paper can meet the passing requirement.

There are several types and materials of articles that can be published. They can be found in the Rector's Regulation of UM No. 17 of 2015, Section 61 which involve article, review article, and research article. The term article alone is also defined variously. The article can be a review, research report, library research, and developmental research. One thing to consider is that the article should be free of plagiarism. Any scientific paper to be published should attach the author's identity. It should follow the applied requirement, that is the Rector's Regulation of UM No. 17 of 2015, Section 62 which says that authors' identity include not only the student's but also the advisors'. The institution ideitity is also included as an institution/ affiliation of where they work.

Scientific paper publication has been accepted as one of requirements for passing the university level. Ideally, university students should understand the policy, therefore their daily activities in the campus can be better directed and focused on writing scientific paper. Student's comprehension towards scientific paper as a passing requirement can be explained as follow. In Kamus Besar Bahasa Indonesia (2016) comprehension can be defined as a process, behavior, way to understand and find out appropriately. A person has the comprehension about something if she or he truly comprehends it. Comprehension can also be defined as: (1) the act or process of comprehending; (2) the state of being comprehended; (3) perception or understanding; and (4) capacity of the mind to perceive and understand; power to grasp ideas; ability to know (Dictionary, 2016). Understanding is something we are knowledgeable about and truly understand (Chaniago, 2002). Comprehension is the way one maintains, estimates, clarifies, extends, concludes, generalizes, exemplifies, rewrites, and calculates (Arikunto, 2009). Comprehension can also be stated as a systematic way.

Comprehension is the degree of university student's understanding toward the policy of scientific paper publication as a passing requirement. A student has comprehended the policy when she or he really understands (higher comprehension degree) the policy. If she or he does not understand it, they might have lower understanding. Comprehension also refers to student's individual skill in perceiving, understanding, sensing, and concluding the information related to the scientific paper publication, and other conditions to pass the university degree.

Understanding the content of scientific paper is a strategic approach for the students in finishing their study, in which they should understand what is written in it. The degree of the student's comprehension 
towards the policy of publishing scientific paper as a passing requirement can reflect their response towards it as well. As written in Kamus Besar Bahasa Indonesia (2016), response can be defined as a form of feedback, reaction, and answer to something. This 'something' in this context is the policy of scientific publication as a passing requirement. Attitude refers to one's behavior etc, related to one's stance, faith (Kamus Besar Bahasa Indonesia, 2016). In this context, attitude indicates the students' behavior related to their stance and faith (especially their comprehension) towards the policy of scientific paper publication as a passing requirement. This definition shows that attitudinal response referred here is feedback, reaction, and answer which is in accordance with the students' stance and faith towards the policy. The later definition is to be used in this paper.

There are several obstacles faced by students writing scientific paper. Mujiyah (2001) shows the findings of her study, as follows: Several obstacles when students are struggling with their final assignment or thesis are identified, such as internal obstacles including laziness (40\%), low motivation $(26.7 \%)$, fear of seeing the advisors $(6.7 \%)$, difficulty to adjust with the advisors $(6.7 \%)$. External obstacles which come from the advisors include minimum availability for scheduling appointment $(36.7 \%)$, limited consultation time $(23.3 \%)$, lack of coordination and agreement between the perception of advisor 1 and 2 (23.3\%), unclear guidance in consultation $(26,7 \%)$, and highly scheduled lecturers $(13.3 \%)$. Obstacles from source books include limited reference books which focus on the problems of study $(53.3 \%)$, reference books available are old $(6.7 \%)$. Obstacles from supporting facilities include limited funding with the thesis material, obstacles when determining titles or study problems (13.3\%), confusion in developing theories (3,3\%). Methodological obstacles include author's limited knowledge of methodologi $(10 \%)$, difficulty to find teacher with expertise in research method and analysis of instrument validation $(6.7 \%)$.

Another study by Rahmiati (2014) indicates the following findings: problems faced emerge from the students, namely lack in skills, no motivation, difficulty to start, limited horizon, and linguistic problems. Besides, problems also occur from the student's environment, such as lack of early habituation, lack of motivation from the study environment, more learning time focusing on the conceptual level, limited rooms for training writing scientific paper, minimum appreciation from academics, the curriculum which does not include writing scientific paper comprehensively, limited time allocated for writing and lack of financial support. The study findings indicate several obstacles faced by students in writing scientific paper (thesis). The obstacles may occur from internal and external factors. All obstacles should be identified and appropriate solutions (attempts) should be found to deal with the obstacles. Such obstacles can indeed trouble the process of writing and publishing the scientific paper for the student's passing requirement. If ignored, these obstacles may badly impact the student's completion of study, thus anticipatory attempts are necessary.

Any time facing obstacles related to scientific paper publication, university students are required to find the solutions. These solutions may vary, depending on the obstacle faced. There are several endeavors students can do to deal with the obstacles related to scientific paper publication. Idehidup (2016) suggests instructions of the endeavors, such as: (1) reinforcing background of why such topic is chosen (introduction); (2) reinforcing research method; (3) being consistent in writing, (4) minimizingtypos, (5) synchronizing citation in the text body with that on the reference page, (6) re-reading the draft of scientific paper, and (7) asking for others (peers, colleagus, etc.) to proofread the draft.

Aside from the previously mentioned endeavors, students can also do others when dealing with obstacles. Idehidup (2016) provides reference of attempts or endeavors when facing the obstacles of writing and publishing scientific paper, namely: (1) once you are feeling indolent of writing the paper, you should reinforce your aim, (2) if you are a type of individual who likes procrastinating, do anything can be done or possible to be done immediately, (3) if you feel like you have limited knowledge and experience in writing scientific paper, cope with it by more reading and learning relevant books or articles thoroughly, limited experience can be dealt with by more writing scientific paper and participating writing events, (4) no/ limited mastery of the selected topic to be discussed in the scientific paper, the students can keep learning and adding more information or knowledge related to the topic, and discussing with experts, (5) if you lack reading literature, read and cite the works by inserting them into your paper, (6) if the available literature is not adequate, some online sources are also trustworthy (Elsevier, Science Direct, Proquest, and the like), (7) if you cannot review your writing, read and check it once it is done, and (8) implant the idea of never plagiarizing to yourself.

The previously stated suggestions of dealing with obstacles when writing or publishing scientific paper can be adopted by students. These endeavors should be adjusted to the kind of obstacle faced so that the process of writing and publishing scientific paper can be performed well as a passing requirement. Several attempts done by the researcher are among others conducting research on institution readiness, supporting and hampering factors, and strategies in enhancing student's publication as a consequence of Letter issued by Dirjen Dikti No. 152/E/T/2012 o tn Scientific Paper Publication in the environement of higher education in Indonesia. The outputof the study is scientific paper whose publication is currently processed for the international jounal.

The state of the art in this investigation is that it will reveal information related to comprehension and attitudinal responses of students towards the policy of publishing scientific paper as a requirement for passing the university level. The process of writing scientific paper is also not free of obstacles. The students face obstacles and have to deal with them appropriately in 
order to be able to complete the passing requirement. The findings will also be reported in scientific article which is to be published in an international journal. Based on the description above, the researcher sees the importance of conducting a study which aims to investigate "Comprehension, Attitudes, Obstacles, and Endeavors of University Students Dealing with Scientific Paper Publication as a Passing Requirement".

\section{METHODS}

This study employs descriptive design which is approached quantitatively. As written in the aim of the study, this study will describe a symptom, incident, phenomenon which occur at the moment or any real problem as it is during the study conduct without giving any treatment to the phenomenon (Darma, 2008), especially comprehension, attitudes, obstacles, and endeavors of university students dealing with scientific paper publication as a passing requirement.

Population, as stated by Arikunto (2006) is "every research subject has common characteristics."'The population of this study includes undergraduate students of 2013 year of entrance at Department of Educational Administration FIP UM. The main rationale of selecting them as the study population is that they are currently finishing their scientific paper (especially thesis) and will be required to publish it as a passing requirement. The total number of population is 100 students. Considering the relatively homogeneous population and that the total number is below 100, this study employed saturated sampling. It means that all students of 2013 year of entrance at Department of Educational Administration FIP UM are respondents of the study.

Several variables are investigated, including the implementation of Form Letter of Dirjen Dikti No. 152/E/T/2012 and Scientific Paper Publication. Both variables, sub-variables, and research indicators are developed and described by the researcher in accordance with the issued document and relevant literatute, and the researcher's independent thought. The variables, sub-variables, and research indicators can be seen in Table 1. The variables are comprehension, attitudes, obstacles, and endeavors of university students dealing with scientific paper publication. Additionally, the sub-variables include: student's comprehension towards scientific paper publication, student's attitudes towards scientific paper publication,obstacles the students face when completing the requirement of publishing scientific paper, and the endeavors they make to deal with the requirement.

Table 1

Variable, Sub-variable, and Indicators

\begin{tabular}{|c|c|c|}
\hline Variable & Sub-variable & Indicators \\
\hline \multirow[t]{3}{*}{$\begin{array}{l}\text { Comprehension, } \\
\text { attitudes, } \\
\text { obstacles, and } \\
\text { endeavors of } \\
\text { university } \\
\text { students dealing } \\
\text { with scientific } \\
\text { paper } \\
\text { publication }\end{array}$} & $\begin{array}{l}\text { Student's } \\
\text { comprehension } \\
\text { towards scientific } \\
\text { paper publication }\end{array}$ & $\begin{array}{l}\text { 1. Scientific paper publication } \\
\text { 2. Academic work } \\
\text { 3. Scientific article } \\
\text { 4. Creative work } \\
\text { 5. Academic work publication } \\
\text { 6. Nationally reputated scientific journal } \\
\text { 7. Internationally reputated scientific journal } \\
\text { 8. National proceeding } \\
\text { 9. International proceeding } \\
\text { 10. Creative work publication } \\
\text { 11. Status of scientific paper publication } \\
\text { 12. Requirements/format of academic paper publication } \\
\text { 13. Types and material of published article } \\
\text { 14. Attachment of scientific article identity } \\
\text { 15. Equivalence and acknowledgement of publication } \\
\text { 16. Publication as examination requirement }\end{array}$ \\
\hline & $\begin{array}{l}\text { Student's attitudes } \\
\text { towards scientific } \\
\text { paper publication }\end{array}$ & $\begin{array}{l}\text { 17. Scientific paper publication } \\
\text { 18. Academic work } \\
\text { 19. Scientific article } \\
\text { 20. Creative work } \\
\text { 21. Academic work publication } \\
\text { 22. Nationally reputated scientific journal } \\
\text { 23. Internationally reputated scientific journal } \\
\text { 24. National proceeding } \\
\text { 25. International proceeding } \\
\text { 26. Creative work publication } \\
\text { 27. Status of scientific paper publication } \\
\text { 28. Requirements/format of academic paper publication } \\
\text { 29. Types and material of published article } \\
\text { 30. Attachment of scientific article identity } \\
\text { 31. Equivalence and acknowledgement of publication } \\
\text { 32. Publication as examination requirement }\end{array}$ \\
\hline & $\begin{array}{l}\text { Obstacles the } \\
\text { students face } \\
\text { when completing } \\
\text { the requirement of } \\
\text { publishing } \\
\text { scientific paper }\end{array}$ & $\begin{array}{l}\text { 33. Indolent } \\
\text { 34. Low motivation } \\
\text { 35. Fear of seeing advisors } \\
\text { 36. Difficulty to adjust with the advisors } \\
\text { 37. Minimum available time for appointment } \\
\text { 38. Minimum consultation time } \\
\text { 39. Lack of coordination and agreement of perception between advisors } \\
\text { 40. Unclear guidance in consultation }\end{array}$ \\
\hline
\end{tabular}




\begin{tabular}{|c|c|c|}
\hline Variable & Sub-variable & Indicators \\
\hline & & $\begin{array}{l}\text { 41. Highly scheduled lecturers } \\
\text { 42. Minimum books of reference focusing on the study problems } \\
\text { 43. References available are old edition } \\
\text { 44. Limited funding with the paper material } \\
\text { 45. Determination of study title and problems } \\
\text { 46. Confusion in developing theories } \\
\text { 47. Limited knowledge of authors about methodology } \\
\text { 48. Difficulty to find teacher with expertise in research method and analysis of instrument validation }\end{array}$ \\
\hline & $\begin{array}{l}\text { Student's } \\
\text { endeavors to deal } \\
\text { with the obstacles } \\
\text { when fulfilling } \\
\text { the scientific } \\
\text { paper publication } \\
\text { as a passing } \\
\text { requirement }\end{array}$ & $\begin{array}{l}\text { 49. Reinforcing background of why such topic is chosen (introduction) } \\
\text { 50. Reinforcing research method } \\
\text { 51. Being consistent in writing } \\
\text { 52. Minimizing typos } \\
\text { 53. Synchronizing citation in the text body with that on the reference page } \\
\text { 54. Re-reading the draft of scientific paper } \\
\text { 55. Asking for others (peers, colleagus, etc.) To proofread the draft } \\
\text { 56. Once you are feeling indolent of writing the paper, you should reinforce your aim } \\
\text { 57. If you are a type of individual who likes procrastinating, do anything can be done or possible to be } \\
\text { done immediately } \\
\text { 58. If you feel like you have limited knowledge and experience in writing scientific paper, cope with it } \\
\text { by more reading and learning relevant books or articles thoroughly, limited experience can be dealt } \\
\text { with by more writing scientific paper and participating writing events } \\
\text { 59. No/ limited mastery of the selected topic to be discussed in the scientific paper, the students can } \\
\text { keep learning and adding more information or knowledge related to the topic, and discussing with } \\
\text { experts } \\
\text { 60. If you lack reading literature, read and cite the works by inserting them into your paper } \\
\text { 61. If the available literature is not adequate, some online sources are also trustworthy (Elsevier, } \\
\text { Science Direct, Proquest and the like) } \\
\text { 62. If you cannot review your writing, read and check it once it is done } \\
\text { 63. Participating training/ workshop for writing scientific paper } \\
\text { 64. Implant the idea of never plagiarizing to yourself. }\end{array}$ \\
\hline
\end{tabular}

A questionnaire used as an instrument in this study was developed based on the variables, subvariables, and measuring indicators. The questionnaire comprises of close-ended and semi-open ended. This instrument, before used to gather data is tested for its validity and reliability. The validity test is aimed to identify number of valid and invalid items. These valid items were then used to collect effective data from the respondents. Practically, the validity test used the formula of Correlation Coefficient Statistics of Product Moment and SPSS for Windows.

To investigate whether the data are valid or not, it is observed from the results of correlation coefficient measurement to every questionnaire item which are compared to the comparator value in Table $r$
Critique Product Moment. Such comparator value in the table is found based on the number of study samples and the preferred degree of freedom. The criteria of validity test is based on the assertion: if value of the correlation coefficient measurement in every item is greater than the comparator in Table $r$ Critique Product Moment ( $\mathrm{r}$ count $>\mathrm{r}$ table), the questionnaire item is valid; vice versa.

Reliability test is required for ensuring the trustworthiness of the instrument. Once it is reliable, the instrument will not cause different interpretations from the respondents.Realibility test can use a statistical formula with Alpha Chrombach analysis technique. The result of this test indicates that the score has met the standard, as seen in Table 2.

Table 2

Results of Instrument Validity and Reliability Test

\begin{tabular}{lcc}
\hline \multicolumn{1}{c}{ Variable } & Reliability & Validity \\
\hline Student's comprehension & 0,897 & 0,562 \\
Student's attitude toward the Scientific Paper Publication & 0,930 & 0,649 \\
Obstacles faced by students when writing scientific paper & 0,866 & 0,499 \\
Student's endeavors to deal with the obstacles when writing scientific paper & 0,922 & 0,625 \\
\hline
\end{tabular}

Data were gathered using the questionnaire distributed to respondents. The technique of descriptive analysis used to indicate comprehension, attitudes, obstacles, and endeavors of students to the policy of scientific paper publication as a passing requirement in university level. Mean of the variables are measured using SPSS.

\section{RESULTS}

Student's Comprehension towards Scientific Paper Publication

Student's comprehension towards scientific paper publication as a passing requirement is illustrated in Figure 1. According to the percentage, $11.8 \%$ of the respondents are classified in the low category, $16.8 \%$ of the respondents are in the moderate, and the rest $71.6 \%$ are classified in the high category that also indicate the level of understanding of the respondents towards scientific paper publication as a passing requirement.

Based on the result of mean calculation (Table 3 ), it is known the degree of students' comprehension towards scientific paper publication as a passing requirement, and that the mean score obtained is 43.146 which is classified as moderate. 


\section{Student's Attitudes towards Scientific Paper Publication}

As seen in Figure 2, it is illustrated that 24.2\% of the respondents are in the low category, $17.90 \%$ are in the moderate category, and the other $57.9 \%$ of respondents indicate the students' attitudes towards scientific paper publication as a passing requirement.

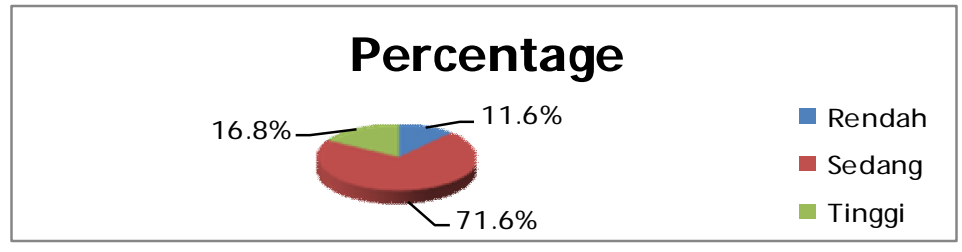

Figure 1

Percentage of the Degree of Student's Comprehension towards Scientific Paper Publication as a Passing Requirement

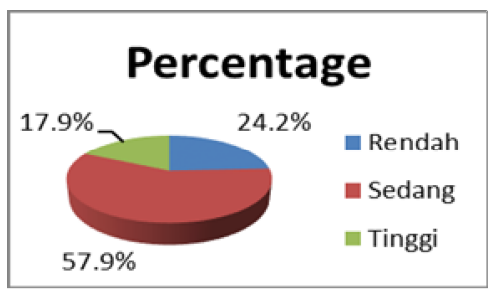

Figure 2

Percentage of Student's Attitudes towards Scientific Paper Publication as a Passing Requirement

According to the result of mean calculation (Table 3), the degree of students' comprehension towards scientific paper publication as a passing requirement can be observed, and that the mean score obtained is 43.814 which is classified as moderate.

\section{The Degree of Obstacles the Students Face When} Completing the Requirement of Publishing Scientific Paper

Based on the result of analysis, Figure 3 presents the percentage of obstacles the students face when completing the requirement of publishing scientific paper as a passing requirement. It is described as $13.7 \%$ are in the low category, $12.6 \%$ are in the moderate category, and $73.7 \%$ of the respondents who show the attitudes toward the policy of publishing scientific paper as a passing requirement.

According to the result of mean calculation (Table 3), it is known that the degree of obstacles the students face when completing the requirement of publishing scientific paper as a passing requirement obtained the mean score of 43,814 which is classified as moderate

\section{Student's Endeavors to Deal with the Obstacles when Fulfilling the Scientific Paper Publication as a Passing Requirement \\ The endeavors and the result of analysis as illustrated in the percentage of student's endeavors to deal with the obstacles when fulfilling the scientific paper publication as a passing requirement can be seen in Figure 4. The figure is described as $48.4 \%$ of the respondents are in the low category, $73.7 \%$ are categorized as moderate, and $49.57 \%$ of the respondents indicate the student's attitude towards the policy of publishing scientific paper as a passing requirement.}

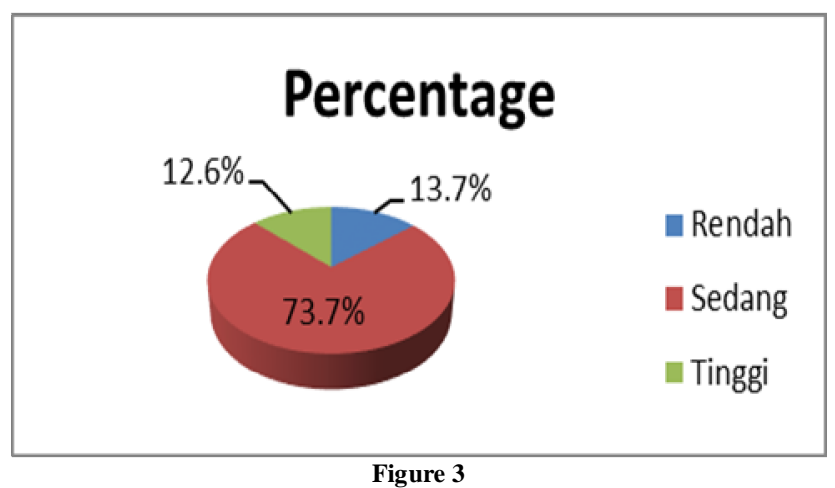

Percentage of Obstacles the Students Face When Completing the Requirement of Publishing Scientific Paper 


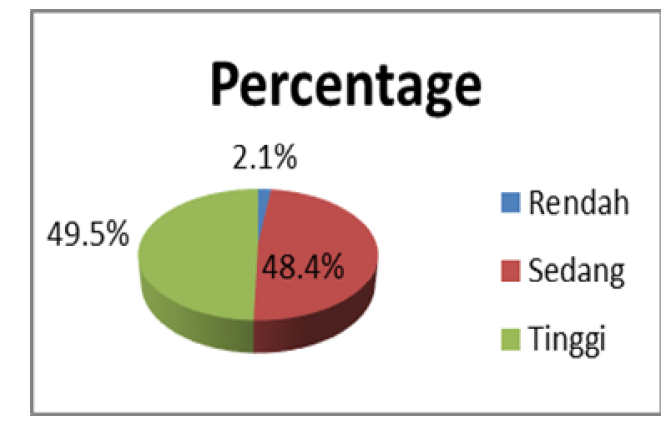

Figure 4

Percentage of Student's Endeavors to Deal with the Obstacles when Fulfilling the Scientific Paper Publication as a Passing Requirement

Table 3

A Summary of Results of Data Analysis

\begin{tabular}{|c|c|c|c|c|}
\hline $\begin{array}{c}\text { Variable } \\
\text { Parameter } \\
\end{array}$ & Comprehension & Attitudes & Obstacles & Endeavors \\
\hline Mean & 43.146 & 43.814 & 42.542 & 56.491 \\
\hline Standar Deviation & 8.582 & 10.279 & 8.248 & 10.081 \\
\hline Variance & 73.652 & 105.670 & 68.042 & 101.640 \\
\hline Curtosis & -0.701 & -0.588 & -0.350 & 0.471 \\
\hline Skewness & 0.117 & -0.137 & 0.386 & -0.366 \\
\hline Score Min & 21.742 & 20.872 & 28.459 & 24.466 \\
\hline Score Max & 59.779 & 69.465 & 63,670 & 78.327 \\
\hline Range & 38.037 & 48.592 & 35,211 & 53.861 \\
\hline Sum & 4098.874 & 4162.346 & 4041,530 & 5366.670 \\
\hline N (Sampel) & 95 & 95 & 95 & 95 \\
\hline Max Chances & 72.074 & 74.851 & 69.769 & 78.327 \\
\hline Min Chances & 15.000 & 15.000 & 14.000 & 16.000 \\
\hline Range Chances & 57.074 & 59.851 & 55.769 & 62.327 \\
\hline Interval & 19.024 & 19.950 & 18,589 & 20.775 \\
\hline Low Category & $\leq 34.024$ & $\leq 34.950$ & $\leq 32.589$ & $\leq 36.775$ \\
\hline Moderate Category & $\leq 53.049$ & $\leq 54.900$ & $\leq 51.179$ & $\leq 57.551$ \\
\hline High Category & $\geq 53.049$ & $\geq 54.900$ & $\geq 51.179$ & $\geq 57.551$ \\
\hline
\end{tabular}

According to the result of mean calculation (see Table3), it is known that the percentage of student's endeavors to deal with the obstacles when fulfilling the scientific paper publication as a passing requirement obtained the mean score of 56,49, meaning that it is categorized as moderate. Seeing the results of data analysis as presented previously, an integrated summary can be made (comprehension, attitudes, obstacles, and endeavors of university students dealing with scientific paper publication as a passing requirement) as presented in Table 3.

As integrated in Table 3, the results of analysis is shows that the students' comprehension towards scientific paper publication as a passing requirement is classified in the moderate category,that the students' attitudes show the 'fairly agree' attitude (moderate category), and that obstacles the students face are also in the moderate category. The endeavors made by the students when dealing with the obstacles are categorized as moderate, as well. The results of analysis indicate that comprehension, attitudes, obstacles, and endeavors of university students dealing with scientific paper publication as a passing requirement are categorized as moderate.

\section{DISCUSSION}

Student's Comprehension towards Scientific Paper Publication

Student's comprehension towards scientific paper publication as a passing requirement is found moderate in this study. It may be interpreted that the respondents have understood kinds of scientific paper and its publication in the fair manner, not bad but not so good. The degree of their comprehension is just ordinary. The ordinary or fair degree of individual comprehension towards an object reflects that their comprehension is not yet optimal. In this study, it is assumed that the respondents have not comprehensively understand scientific paper publication, and that they have not received optimal information, and neither they have received adequate socialization from the institutions, nor found the policy of scientific paper publication as a passing requirement.

The obtained results are relevant with the statement that one is considered to comprehend something when one has truly understood the thing (Kamus Besar Bahasa Indonesia, 2016), and that apparently they have not identified any systematic strategy to comprehend and express their idea about scientific paper (Harja, 2011). The latter would mean that students have not comprehensively understand the policy of scientific paper publication as a passing requirement.

\section{Student's Attitudes towards Scientific Paper Publication}

Student's comprehension towards scientific paper publication as a passing requirement is found moderate, as it is also found to be fairly agree or 
moderate with their attitudes. These findings seem to be interrelated.

The attitude as previously described is one's behavior etc. related to the stance and faith held by the students (Kamus Besar Bahasa Indonesia, 2016). This reflects that feedbacks, reaction, and answers to policy of scientific paper publication as a passing requirement have not been classified as optimal. The students' attitudes should be optimized in order to be better prepared and motivated in writing and publishing scientific paper.

\section{Obstacles the Students Face When Completing the Requirement of Publishing Scientific Paper}

The obstacles that are faced by the students when completing the requirement for publishing scientific paper as a passing grade is categorized as moderate. It is interpreted that the students do not find serious troubles when writing and publishing scientific paper. Still, the obstacles are there. In this regard, obstacles are faced by the students wbo are struggling with writing and publishing the scientific paper.

Among the existing obstacles, several require more concerns, like those from the internal side of students, namely indolence and low motivation, and those from the external side, the most marked obstacles, namely limited availability of relevant references and minimum availability time for apppointment (Mujiyah, 2001). This is in line with the study findings by Rahmiati (2014:1) indicating that problems faced emerge from inside of the students, namely lack in skills, no motivation, difficulty to start, limited horizon, and linguistic problems. While the problems emerge from outside of the students are minimum appreciation from academics and the curriculum which does not include writing scientific paper comprehensively.

\section{Student's Endeavors to Deal with the Obstacles when Fulfilling the Scientific Paper Publication as a Passing Requirement \\ Endeavors of students to deal with the} obstacles when fulfilling the scientific paper publication as a passing requirement is found to be moderate. Should this be ignored, the results will be less optimal. Ideally, the endeavor the students do must be optimal thus it can optimally impact the fulfillment of the policy. The endeavors that are possible to be done by the students in dealing with the obstacles may follow the good instructions. These include several attempts, like reinforcing background of why such topic is chosen (introduction), research method, being consistent in writing, minimizing typos, synchronizing citation in the text body with that on the reference page, re-reading the draft, and asking for others to proofread the draft (Idehidup, 2016)

Idehidup (2016) also suggests several endeavors for students when facing obstacles in writing and publishing scientific paper.They include: reinforcing the aim once indolence comes, if procrastinating is a habit, immediately do anything possible, if lacking of experience in writing scientific paper, read more and learn relevant books and articles more deeply, if lacking in experience, write more scientific paper and participate in events; if lacking the mastery of the scientific paper on project, students can keep learning and increasing topic related knowledge and discuss with experts; if not enough reading literature, read more and cite the work by inserting to the paper; if there is not enough available literature, read online sources; if checking work is not possible, check it when it is done; implant the idea of never plagiarizing.

The previously stated suggestions of dealing with obstacles when writing or publishing scientific paper can be adopted by students. These endeavors should be adjusted to the kind of obstacle faced so that the process of writing and publishing scientific paper can be performed well as a passing requirement. Yet, it is also necessary for the students to set target of completion and comply with it thus they can predict the completion time.

\section{CONCLUSIONS AND SUGGESTIONS Conclusions}

According to the data analysis and discussions of the study findings, some points of conclusions are stated in the following: (1) comprehension of the university students dealing with the scientific paper publication is in the moderate category; (2) the attitudes are also categorized as moderate; (3) the obstacles faced by the students when dealing with the scientific paper publication is moderate as well; and (4) the endeavors they make to cope with the obstacles that occur when dealing with the scientific paper publication as a passing requirement also indicates moderate.

\section{Suggestions}

The researcher proposes several suggestions to: (1) university students are to be made clear since their first days to campus thus when the policy of writing scientific paper and its publication are held, the students have comprehended it and can complete it easily. It is also important to develop students' positive attitudes since their first days to campus to make them better prepared in writing and publishing scientific paper. Additionally, the obstacles which are predicted to occur and be faced by students have to be minimized so that the students can fulfill their duties as best as possible. Finally, the students' endeavors in dealing with the obstacles must be improved so that they can complete the requirement faster and better; (2) lecturers should show exemplary attitude when giving advises to students in writing and publishing scientific paper; (3) institution should make a policy related to institutional strategy in improving the students' comprehension, attitudes, and in accelerating the writing and publication of scientific paper; and (4) prospective researchers, that it is important that they continue the study which focuses on the quality aspects of the scientific paper publication as a passing requirement, management of scientific paper publication, and productivity as well as appreciation to authors for their published work, and the tendency of the degree of 
scientific paper publication in the higher educational institutions.

\section{REFERENCES}

[1] Arikunto, S. 2006. Prosedur Penelitian Suatu Pendekatan Praktek. Yogyakarta: Rineka Cipta.

[2] Arikunto, S. 2009. Dasar-Dasar Evaluasi Pendidikan. Jakarta: Bumi Aksara.

[3] Badan Pengembangan dan Pembinaan Bahasa. 2016. Kamus Besar Bahasa Indonesia. Jakarta: Pusat Bahasa, Kemdikbud.

[4] Chaniago, A. Y. S. 2002. Kamus Lengkap Bahasa Indonesia. Bandung: Pustaka Setia.

[5] Dictionary. 2016. Comprehension. Retrieved December 20, 2016, from http://www.dictionary.com/ browse/comprehension.

[6] Dirjen Dikti. 2012. Surat Edaran Dirjen Dikti Nomor 152/E/T/2012 tentang Publikasi Karya Ilmiah. Jakarta: Dikti.

[7] Djamaan, A. 2012. Publikasi di Jurnal Ilmiah: Kalau Tidak Sekarang, Kapan Lagi? Retrieved December 20, 2016 , from https://profakmaldjamaan.wordpress.com/2012/03/20/p ublikasi-di-jurnal-ilmiah-kalau-tidak-sekarang-kapanlagi/.

[8] Harja, M. 2011. Pemahaman Konsep dalam Pembelajaran Matematika dengan Pendekatan Konstruktivisme. Retrieved December 20, 2016, from http://mediaharja.blogspot.co.id/2011/11/pemahamankonsep.htm.

[9] Idehidup. 2015. Kendala Menulis Karya Ilmiah dan Cara Mengatasinya. Retrieved December 20, 2016, from http://idehidup.com/8-kendala-menulis-karyailmiah-dan-cara-mengatasinya.
[10] Idehidup. 2016. Cara Mengatasi Kesalahan Penulisan Karya Tulis Ilmiah. Retrieved December 20, 2016, from http://idehidup.com/7-cara-mengatasi-kesalahanpenulisan-karya-tulis-ilmiah/.

[11] Peraturan Rektor Nomor 17 Tahun 2015 tentang Pedoman Akademik Universitas Negeri Malang Tahun akademik 2015/2016. Malang: State University of Malang.

[12] Peraturan Rektor UB Nomor 595/PER/2011 tentang Tugas bagi Dosen, Mahasiswa, Fakultas, Unit Kerja dan Alumni dalam Program peringkatan Internasional melalui Publik. Malang: Brawijaya Univerisity.

[13] Peraturan Rektor Universitas Brawijaya Nomor 336/PER/2012 tentang Penerbitan Karya Ilmiah pada Terbitan Berkala Ilmiah sebagai Syarat Kelulusan pada Pendidikan Program Sarjana, Magister, dan Doktor di Universitas Brawijaya. Malang: Brawijaya Univerisity.

[14] Peraturan Rektor Universitas Negeri Malang Nomor 6 Tahun 2015 Tentang Suplemen Buku Pedoman Pendidikan Universitas Negeri Malang Tahun 2014. Malang: State University of Malang.

[15] Rahmiati. 2014. Problematika Mahasiswa Dalam Menulis Karya Ilmiah. Jurnal Al Hikmah, XV(1), 90106.

[16] Universitas Negeri Malang. 2010. Pedoman Penulisan Karya Ilmiah. Malang: Universitas Negeri Malang.

[17] Universitas Negeri Malang. 2015. Jurusan dan Prodi. Retrieved December 20, 2016, from https://www.um.ac.id/page/jurusan-dan-prodi.

[18] Zain, N. F. M. 2013. Masih Butuh Waktu. Retrieved December 20, 2016, from http://edukasi.kompasiana.com/ 2012/03/14/masihbutuh-waktu. 